\title{
SENSITIVITY ANAL YSIS OF DECORATIVE PLANT BUSINESS IN KENDARI CITY (CASE STUDY ON DAHLIA ORNAMENTAL PLANT BUSINESS)
}

\author{
Rabiatul Adawiah Gasnawati ${ }^{\left.{ }^{*}\right)}$, Abdi $^{1}$, Awaluddin Hamzah ${ }^{1)}$ \\ ${ }^{1}$ Department of Agribusiness, Faculty of Agriculture, Halu Oleo University Kendari 93232 \\ ${ }^{*}$ Corresponding author : radawiah191@gmail.com
}

To cite this article:

Gasnawati, R., Abdi, A., \& Hamzah, A. (2021). Sensitivity Analysis of Decorative Plant Business in Kendari City (Case Study on Dahlia Ornamental Plant Business). International Journal of Agricultural Social Economics and Rural Development (ljaserd), 1(1), 13 - 16. doi:http://dx.doi.org/10.37149/ijaserd.v1i1.14159

Received: September 20, 2020; Accepted: October 31, 2020; Published: January 31, 2021

\begin{abstract}
The purpose of this study was to determine the sensitivity of ornamental plant business in Kendari City as a case study on dahlia ornamental plant business. This research was conducted in Kendari City which was determined purposively on the dahlia ornamental plant business. The research was conducted from July to November 2019. The analysis used in this study is an analysis of efficiency and income consisting of net present value (NPV) income benefit ratio (NBCR), internal rate of return (IRR), payback period (PBP). The results of the sensitivity analysis of ornamental plant businesses with increased production costs by $5 \%$ and selling prices decreased by $5 \%$, the value of the NPV, NBCR, IRR and payback period shows a good value so that the ornamental plant business is feasible to be cultivated because it can return all investment costs used
\end{abstract}

Keywords: decorative plants; Kendari City; sensitivity

\section{INTRODUCTION}

Agriculture is a very important sector in the national economy. Therefore, the national economic development of the 21st century will still be based on broad agriculture. However, in line with the stages of economic development, agricultural-based services, and business activities will also increase, namely agribusiness activities will become one of the leading sectors of national economic development in a wide variety of aspects. Development activities in Kendari City have been intensively carried out starting in 2008, the government has built a location that can be used as a place of business or ornamental plant business, namely the location for the promotion of ornamental plants and the sale of agricultural products located in Kendari City. The location is very strategic so that ornamental plant lovers, especially ornamental plants, both in the city and outside the city can visit the Location for Promotion of Ornamental Plants. agribusiness, horticulture, ornamental plants, and fruits. Development of the area with the aim that ornamental plant business actors can market their ornamental plants in that place so that people can easily get the plants they need.

Ornamental plants can be in the form of trees, shrubs, shrubs, creeper, vine, clinging, hanging, or as ground cover. Ornamental plants can be cultivated into a business that promises big profits because ornamental plants have high economic value. Ornamental plants have the potential to be used as trade commodities between countries in the world. Planting or collecting ornamental plants has a very large role and function in human life. Ornamental plants are one of the riches of natural resources that are important to study. Ornamental plants have a direct influence on humans ecologically, are used to regulate erosion and coldness, to provide a place for recreation and sports, and to satisfy human desires for objects that are beautiful. Apart from these functions, ornamental plants have very potential business prospects in Indonesia to increase income and expand employment (Hutarabat, 2008).

The sensitivity of ornamental plants by knowing the income of ornamental plants in Kendari City in this study can be seen as analysis to be able to see the effects that will occur due to changing circumstances (Gittinger 1986). In agriculture, changes that occur in business activities can be caused by, increased costs and decreased production costs. Sensitivity analysis is carried out by looking for several replacement values for the cost and benefit components that still meet the minimum eligibility criteria for investment or the maximum NPV value is zero, the IRR value is equal to 
the interest rate and the Net B / C ratio is equal to 1 (Gittinger, 1986). Sensitivity analysis is carried out to test whether a business is still feasible to run at a certain price level by periodically increasing costs (Irfan, 2006). Therefore, researchers are interested in conducting research on the sensitivity analysis of ornamental plant farming. Sensitivity is the level of business sensitivity to changes in cash flow conditions (increase in input, decrease in output, (Mursidi et al, 2011). The conditions studied are if the price of production factors increases by $5 \%$ assuming fixed product prices (Condition I) decreased by $5 \%$ with the assumption that the price of production factors is fixed (Condition II). The purpose of this study was to determine the sensitivity of ornamental plant business in Kendari City as a case study on dahlia ornamental plant business.

\section{MATERIALS AND METHODS}

This research was conducted in Kendari City which was determined purposively on the dahlia ornamental plant business. The research was conducted from July to November 2019. Data analysis used to determine the amount of input (means of production) used in the operation of farming mathematically is as follows (Fitriadi S, 2017)

Information :

$$
\mathrm{TC}=\mathrm{FC}+\mathrm{VC}
$$

$\mathrm{TC}=$ Total Cost (IDR / year)

$\mathrm{FC}=$ Fixed Costs $(\mathrm{IDR} /$ year $)$

$\mathrm{VC}=$ Variable Cost (IDR / year)

To find out the income, the following formula is used:

Information :

$$
\pi=\mathrm{TR}-\mathrm{TC}
$$

$\pi \quad=$ Income $(\mathrm{IDR} /$ year)

$\mathrm{TR}=$ Total Revenue (IDR / year)

$\mathrm{TC}=$ Total Cost (IDR / year)

To find out the feasibility of a business is carried out as follows:

1. Net Present Value (NPV)

2. Net Benefit-Cost Ratio (NBCR)

3. Internal Rate of Return (IRR)

4.Payback Period (PBP)

To determine sensitivity is done with

1. If the price of production factors increases by $5 \%$

2. If the product price drops by $5 \%$

\section{RESULTS AND DISCUSSION}

\section{Respondent Characteristics}

Ornamental plant traders who are scattered almost throughout Kendari City were originally formed on the basis of one of the government programs that have been implemented since 2002, originally formed to provide competitions for regional ornamental plants. The competition activity is a new beginning for traders to cultivate ornamental plants in Kendari City until now.

Table 1. Characteristics of respondents

\begin{tabular}{lc}
\hline \multicolumn{1}{c}{ Variable } & Value \\
\hline Age (Years) & 65 \\
Level of Education & SMA \\
Business Experience (Years) & 15 \\
\hline
\end{tabular}

Source: Primary Data, 2019

Table 1 shows that respondents who sell ornamental plants are categorized as productive. According to Law No. 13 of 2013 concerning manpower, that the productive age category ranges from 15-65 years of age and is not productive / less productive with a range of ages 0-14 years and 55 years and over. Table 1 shows that respondents who sell ornamental plants are high school graduates, this can make it easier for traders to market ornamental plants with their knowledge capital. Table 1 also shows that the ornamental plant trader respondents have 15 years of ornamental plant trading business experience. This experience is very helpful for traders in managing their business because they have learned many things from the experience gained over the years. 


\section{Sensitivity Analysis}

Sensitivity analysis is a technique to see the effects that will occur due to changing circumstances because a project contains a lot of uncertainty about what will happen in the future. Sensitivity analysis is carried out by first knowing the total cost, revenue, and operating income each year to determine the feasibility of the business. Costs, revenues, and business income of ornamental plants can be seen in Table 2 .

Table 2. Costs, revenues, and business income of Dahlia ornamental plants

\begin{tabular}{ccccccc}
\hline \multirow{2}{*}{ No } & \multirow{2}{*}{ Description } & \multicolumn{5}{c}{ Year (IDR) } \\
\cline { 2 - 6 } & & 1 & 2 & 3 & 4 & 5 \\
\hline 1 & Variable Costs & $7,020,000$ & $7,689,600$ & $7,108,800$ & $7,082,400$ & $7,368,000$ \\
2 & Fixed cost & $3,480,000$ & $3,480,001$ & $3,480,002$ & $3,480,003$ & $3,480,004$ \\
3 & Total Cost & $10,500,000$ & $11,169,601$ & $10,588,802$ & $10,562,403$ & $10,848,004$ \\
4 & Reception & $62,580,000$ & $51,960,000$ & $63,480,000$ & $57,000,000$ & $46,980,000$ \\
5 & Income & $52,080,000$ & $40,790,400$ & $52,891,200$ & $46,437,600$ & $36,132,000$ \\
\hline
\end{tabular}

Sumber: Data Primer, 2019

Based on Table 1, it shows that the variable costs in year 2 increased by IDR. 7,689,600 and in years four to year 4 decreased, fixed costs amounted to IDR. 3,480,000, total costs from the first year to the fifth year which had an increase, namely in the second year, namely IDR. 11,169,601, the highest income for ornamental plants was in the first year, namely IDR. 62,580,000, while the highest income was in the third year, namely IDR. 52,891,200.

Based on the results of the feasibility analysis of ornamental plants is feasible to cultivate. This can be seen from the results of the analysis that at the discount factor rate of $15 \%$, the NPV value is IDR $14,521,025$, the NBCR is 1.35 , and the IRR is $40 \%$. Based on the PBP calculation, it is obtained a value of 2.04 years or the investment return period, which means that within that period the investment costs incurred by the business can return.

Sensitivity analysis is carried out if the price of production factors increases by $5 \%$ and the price of the product decreases by $5 \%$. The value of $5 \%$ is the value derived from the Inflation report (Consumer Price Index). This sensitivity analysis is used to see to what extent the ornamental plant business is able to survive any changes that occur in the future.

The condition of the sensitivity analysis with the selling price decreasing by $5 \%$ with a discount factor of $11 \%$, the NPV value of IDR $21,003,077$ is obtained. The results of these calculations indicate that the ornamental plant business is financially feasible to run because the NPV value obtained is positive $(+)$. The NBCR value obtained from this condition is 1.96. From the results of this calculation, it shows that this business is financially feasible to run because the NBCR value is> 1 which means this business is profitable. The IRR value obtained from this calculation is $44 \%$, the results of these calculations indicate that the ornamental plant business is financially feasible because the resulting IRR exceeds the prevailing interest rate, which means that the return on capital is greater than the prevailing interest rate. The PBP value when the selling price decreases by $5 \%$ is 2.04 years or months of return on investment in this business. Details of the calculation of the sensitivity analysis by reducing the selling price by $5 \%$ in the ornamental plant business can be seen in Appendix 20 .

The condition of the sensitivity analysis with increased production costs by $5 \%$ with a discount factor of $11 \%$, the NPV value of IDR.23,125,731 is obtained. The results of these calculations indicate that the ornamental plant business at the dahlia stall is feasible because the NPV value obtained is positive (+) The NBCR value obtained from this condition is 2.16. The calculation results show that this business is financially feasible to run because the NBCR value is $>1$ which means the business is profitable. The IRR value obtained from this calculation is 48 . The calculation results indicate that the ornamental plant business is financially feasible because the resulting IRR value exceeds the prevailing interest rate, which means that the return on capital is greater than the prevailing interest rate. PBP calculation in a condition where production costs increase by $5 \%$ is 1.95 years or 21 months 5 days of investment return period in the business

\section{CONCLUSIONS}

The results of the sensitivity analysis of ornamental plant businesses with increased production costs by $5 \%$ and selling prices decreased by $5 \%$, the value of NPV, NBCR, IRR and payback period shows a good value so that the ornamental plant business is feasible to be cultivated because it can return all investment costs used. 


\section{REFERENCES}

Fitriadi S. (2017). Analisis Sensitivitas Usahatani Budidaya Rumput Gajah Mini Di Kelurahan Syamsudin Noor Kecamatan Landasa Ulin Kota Banjarbaru Provinsi Kalimantan Selatan. Jurnal Media Sains. 10(1): 2355-9136.

Gittinger, J. P. (1986). Analisa ekonomi proyek-proyek pertanian. Universitas Indonesian (UI-Press).

Hutarabat, D. B. P. (2008). Persepsi dan Sikap Masyarakat Kota Bogor Terhadap Anggrek Hitam (Coelogyne pandurata Lindl.) (Study Kasus di Pedagang Tanaman Hias Kota Bogor). Skripsi. Fakultas Kehutanan Institut Pertanian Bogor.

Irfan, Z. (2006). Program Rintisan dan Akselerasi Pemasyarakatan Inovasi Teknologi Pertanian (Prima Tani) di Panampuang, Kabupaten Agam, Propinsi Sumatera Barat. Balai Pengkajian Teknologi Pertanian, Sumatera Barat.

Mursidi, A., Made, S., \& Ambar, A.Z. (2011). Analisis Kelayakan dan Sensitivitas Usaha Penggilingan Padi. Jurnal Kemandirian Edisi 2011. http://internationaljournalpps.wordpress.com/2013/04/16/jurnal-kemandirianedisi-agustus2011. Diakses tanggal 12 Desember 2019 